\title{
Comparative Physiology and Relative Swimming Performance of Three Redhorse (Moxostoma spp.) Species: Associations with Fishway Passage Success ${ }^{\star}$
}

\author{
Charles Hatry ${ }^{1, \dagger}$ \\ Jason D. Thiem ${ }^{1}$ \\ Thomas R. Binder ${ }^{1}$ \\ Daniel Hatin ${ }^{2}$ \\ Pierre Dumont ${ }^{2}$ \\ Keith M. Stamplecoskie ${ }^{1}$ \\ Juan M. Molina ${ }^{1}$ \\ Karen E. Smokorowski ${ }^{3}$ \\ Steven J. Cooke ${ }^{1,4}$ \\ ${ }^{1}$ Fish Ecology and Conservation Physiology Laboratory, \\ Department of Biology, Carleton University, Ottawa, Ontario \\ K1S 5B6, Canada; ${ }^{2}$ Ministère des Ressources Naturelles et de \\ la Faune, Longueuil, Québec QC J4K 2T5, Canada; ${ }^{3}$ Fisheries \\ and Oceans Canada, Great Lakes Laboratory for Fisheries \\ and Aquatic Sciences, Sault Ste. Marie, Ontario P6A 2E5, \\ Canada; ${ }^{4}$ Institute of Environmental Science, Carleton \\ University, Ottawa, Ontario K1S 5B6, Canada
}

Accepted 6/13/2013; Electronically Published 9/23/2013 dhorse, and river redhorse placed second in terms of metabolic recovery and swim speed. Interestingly, fish sampled from the top of the fishway had nearly identical lactate, glucose, and $\mathrm{pH}$ values compared to control fish. Using passive integrated transponders in 2010 and 2012, we observed that passage success and duration were highly variable among redhorse species and were not consistent among years, suggesting that other factors such as water temperature and river flows may modulate passage success. Clearly, additional research is needed to understand how organismal performance, environmental conditions, and other factors (including abundance of conspecifics and other comigrants) interact with fishway features to dictate which fish will be successful and to inform research of future fishways. Our research suggests that there may be an opportunity for a rapid assessment approach where fish chased to exhaustion to determine maximal values of physiological disturbance are compared to fish sampled from the top of the fishway, which could reveal which species (or sizes of fish) are approaching or exceeding their physiological capacity during passage.

\begin{abstract}
Our understanding of biological criteria to inform fish passage design is limited, partially due to the lack of understanding of biological motivators, cues, and constraints, as well as a lack of biological performance evaluations of structures once they are built. The Vianney-Legendre vertical slot fishway on the Richelieu River, Quebec, Canada, passes large numbers of migrating redhorse (Moxostoma spp.) upriver to spawning grounds each year. We evaluated the physiological capacity and relative swimming ability of three redhorse species (Moxostoma anisurum, Moxostoma carinatum, Moxostoma macrolepidotum; silver, river, and shorthead redhorse, respectively) to determine how these biotic factors relate to variation in fishway passage success and duration. Shorthead redhorse had higher maximum metabolic rates and were faster swimmers than silver and river redhorse at their species-specific peak migration temperatures. Blood lactate and glucose concentrations recovered more quickly for river redhorse than for silver and shorthead re-

\footnotetext{
* This paper was submitted in response to a call for papers for a Focused Issue on "Conservation Physiology."

†Corresponding author; e-mail: charles_hatry@rocketmail.com.
}

Physiological and Biochemical Zoology 87(1):148-159. 2014. (C) 2013 by The University of Chicago. All rights reserved. 1522-2152/2014/8701-2149\$15.00. DOI: $10.1086 / 671900$

\section{Introduction}

The use of physiological knowledge to inform resource management and conservation strategies (i.e., conservation physiology; Wikelski and Cooke 2006; Cooke and O'Connor 2010; Cooke et al. 2013) has great potential for applied fisheries issues (Young et al. 2006). However, the application of physiology to fishway science has been limited (Roscoe and Hinch 2010). Recently, some physiological tools have been successful in identifying how fish populations are affected by dams (e.g., Hasler et al. 2009) and fishway passage (Pon et al. 2012). Although fishways are a fairly common mitigation strategy to address river fragmentation, they are rarely subject to adequate biological study to determine whether they are successful (Bunt et al. 2012). Early studies would deem a facility successful if fish were observed (e.g., captured in traps, documented via video, human observation) reaching the top of a fishway, but that approach does not document individuals that fail to do so (Roscoe and Hinch 2010). More recently, studies of fishway success (mostly using biotelemetry) have begun to focus on quantifying fishway attraction (the proportion of a fish population attracted to the fishway entrance) and passage efficiency (the proportion of fish attracted to the fishway that successfully 
ascend; Roscoe and Hinch 2010; Noonan et al. 2012). Recent meta-analyses have revealed that attraction and passage success are highly variable among fishway types and species and in many cases are quite low (Bunt et al. 2012; Noonan et al. 2012). Low passage success contrasts with the fish passage goals present in the literature, namely, the $90 \%-100 \%$ attraction and passage efficiency suggested by Lucas and Baras (2001) and the idea of transparent passage outlined by Castro-Santos et al. (2009). Clearly, our understanding of biological criteria to facilitate fishway passage design is limited, which is due in large part to the lack of knowledge on biological motivators, cues, and constraints, as well as a lack of biological data on fishway performance once they are built (Bernhardt et al. 2005; Castro-Santos et al. 2009; Kemp 2012).

There are many potential factors that influence attraction and passage efficiency at fishways. Successful passage is thought to be driven by the relationship among an individuals' motivation, ability, and behavioral choices, as well as the environmental and hydraulic conditions encountered at a site (Kemp 2012). In other words, one must understand the behavior, endocrinology, sensory physiology, swimming ability, and metabolic capacity of fish and how they interact with complex environmental cues and features (including hydraulic properties such as variable flows, velocity, and turbulence, as well as light, temperature, etc.) to understand the potential mechanisms driving passage success or failure (Castro-Santos et al. 2009; Williams et al. 2012). This type of information is needed if we are to then find out how biotic factors relate to fishway design and success, something that is sorely needed but has been very difficult to do (Kemp 2012; Williams et al. 2012).

Fish behavior in terms of attraction and passage success can be determined by studying a fish's movement both downstream and inside a fishway (e.g., Castro-Santos et al. 1996; Bunt et al. 1999; Hinch and Bratty 2000). Information such as transit times and resting periods can be studied using electronic tagging (e.g., Thiem et al. 2011). The swimming ability of fishes is commonly measured in a laboratory setting where a fish is forced to swim against a current with a known velocity, often generating estimates of critical swimming speed or estimates of time to fatigue (e.g., Peake 2008). Knowledge of the swimming ability of different fishes has been used to identify potential velocity barriers (Peake et al. 1997a, 1997b) and generate models for use in the evaluation of different fishway passage facilities (Haro et al. 2004), thus informing biological design criteria (Rodriguez et al. 2006; Katopodis and Gervais 2012). Physiological methods such as muscle and blood biochemistry and respiratory energetics (e.g., metabolic rate, aerobic capacity) have been identified as useful ways to measure the physiological consequences of fishway passage (e.g., Connor et al. 1964; Dominy 1971; Schwalme et al. 1985; Cocherell et al. 2011; Roscoe et al. 2011; Pon et al. 2012). Additionally, physiological methods have also been used to evaluate factors determining passage success (Peake and Farrell 2004; Hasler et al. 2009; Pon et al. 2009). However, there have been relatively few studies that have evaluated physiological aspects of fishway passage despite the fact that physiology is one of the primary drivers of ability. In their review, Roscoe and Hinch (2010) determined that only $7 \%$ of fishway studies incorporated some measure of fish physiology. The toolbox for studying the mechanistic basis for fishway passage success certainly exists (reviewed in Hasler et al. 2009; Roscoe and Hinch 2010), and various tools and techniques have been used independently, but few studies have attempted to study behavioral and physiological attributes simultaneously to understand the mechanistic basis of differential passage success.

Most studies on fishway passage have focused on salmonids, but there is a need to examine other fish species. Catostomids frequently dominate fish abundance and biomass in North American rivers and are commonly encountered at fishways (e.g., Schwalme et al. 1985; Bunt et al. 2001; Pratt et al. 2009) due to their obligate migratory phase, increasing their susceptibility to river fragmentation (Cooke et al. 2005a). The Richelieu River, Quebec, has a high abundance and diversity of catostomids, particularly of the Moxostoma genus, thus providing a unique opportunity to evaluate passage performance among species. The objective of this study was to evaluate the physiological capacity and swimming ability (in a field laboratory on the riverbank) of three congeneric species of redhorse (Moxostoma anisurum, Moxostoma carinatum, Moxostoma macrolepidotum; silver, river, and shorthead redhorse, respectively) and determine how those biotic factors relate to variation in passage success and duration through a vertical-slot fishway. Specifically, we evaluated swimming ability (time to exhaustion and distance swam per unit time), aerobic scope and recovery, and postexercise blood chemistry, with the expectation that the species with better performance would have higher passage efficiency. For the purpose of this article, we consider the physiological findings in the context of patterns observed in passage success and timing in "Discussion" rather than focusing on an extensive analysis of behavioral data.

\section{Methods}

\section{Study Site and Fish Collection}

The study was conducted at the Vianney-Legendre fishway located on the Richelieu River near St. Ours, Quebec $\left(45^{\circ} 52^{\prime} \mathrm{N}\right.$, $\left.73^{\circ} 09^{\prime} \mathrm{W}\right)$. A detailed description of the fishway can be found by Thiem et al. (2011). Briefly, the fishway is a $85-\mathrm{m}$-long concrete fishway with 16 vertical slots (0.6-m width, 2.3-4.0$\mathrm{m}$ height per slot as you move downstream), with a total rise of $2.65 \mathrm{~m}$ and an average slope of $4 \%$. The fishway is divided into 12 rectangular basins $(3.5 \mathrm{~m} \times 3.0 \mathrm{~m})$, two turning/resting basins with curved walls (2.75-m radius), and a large entry and exit basin. Each basin has a drop of $0.15 \mathrm{~m}$, moving downstream. Experiments were carried out over two seasons due to widespread flooding of the Richelieu River in 2011. Respirometry trials were conducted between May 30 and June 13, 2011. The swimming performance and blood physiology experiments were conducted between April 22 and May 25, 2012. The three redhorse species used in this study (Moxostoma anisurum, Moxostoma carinatum, Moxostoma macrolepidotum; silver, river, and shorthead redhorse, respectively) were captured directly from 
a fish trap located at the top of the fishway. The fish trap is a $2.2 \times 2.0 \times 2.15-\mathrm{m}$ cage designed for the general purpose of enumerating fish that have moved up the fishway. The fish trap was emptied once per day for the duration of the study. We assumed that capture in the fish trap of large numbers of redhorse by species indicated optimal timing of migration (Quebec Ministère des Ressources Naturelles et de la Faune, unpublished data) and thus conducted experiments for each species as they were encountered. To allow for recovery from capture, we held fish on-site for $24 \mathrm{~h}$ prior to all experimentation in 2,250-L flow-through hatchery tanks (with water pumped directly from the river replaced at a rate of $50 \mathrm{~L} \mathrm{~min}^{-1}$ ). Fish were not fed, to allow for gut clearance. It was not possible to capture fish downstream using nets or electrofishing, given the presence of critically endangered copper redhorse (Moxostoma hubbsi) and concerns regarding their incidental capture. In 2012, the water temperatures (mean hourly) experienced by fish during peak migration windows were reasonably stable such that experiments for a given species occurred within a relatively narrow temperature range (silver redhorse, $9.6^{\circ} \pm 0.4^{\circ} \mathrm{C}$; river redhorse, $16.4^{\circ} \pm 0.3^{\circ} \mathrm{C}$; shorthead redhorse, $9.9^{\circ} \pm 0.4^{\circ} \mathrm{C}$ ) common for migrations of these species (Reid 2006). Rather than conduct experiments at a fixed temperature for all species, it was deemed more ecologically relevant to conduct experiments at ambient temperatures that coincided with the peak migration time for each species.

\section{Respirometry Study}

Aerobic capacity and recovery from exhaustive exercise were compared among silver redhorse $(n=9$, mean $\pm \mathrm{SD}$, $408 \pm 20 \mathrm{~mm}$ total length $[\mathrm{TL}])$, river redhorse $(n=9$, $571 \pm 59 \mathrm{~mm} \mathrm{TL})$, and shorthead redhorse $(n=9,337 \pm$ $15 \mathrm{~mm}$ TL). Fish were initially chased to exhaustion in an annular swim flume (diameter, $130 \mathrm{~cm}$; water depth, $40 \mathrm{~cm}$; at ambient water temperature) before being transferred into cylindrical polycarbonate respirometry chambers (length, 75 $\mathrm{cm}$; radius, $10 \mathrm{~cm}$; volume, $23.55 \mathrm{~L}$ ). Mean hourly temperatures during the respirometry experiments during the 2011 season were as follows for each species: silver redhorse, $13.4^{\circ} \pm 0.1^{\circ} \mathrm{C}$; river redhorse, $15.8^{\circ} \pm 0.1^{\circ} \mathrm{C}$; shorthead redhorse, $13.7^{\circ} \pm$ $0.1^{\circ} \mathrm{C}$; these fall within normal temperature values for spawning migrations of these species (Reid 2006). Exhaustion for a fish was determined when the fish was unable to right itself after 2 s following standard chasing by hand, including tail poking and pinching (Wood 1991). Each respirometry chamber was connected to two standard aquarium pumps (Maxi-Jet 900, Marineland Aquarium Supplies), with one pump recirculating water through the chamber and the other pump periodically pumping fresh oxygenated river water into the chamber.

It was not possible to measure standard metabolic rate due to field site restrictions. Instead, we adopted a model where we chased fish to exhaustion and then monitored their metabolic recovery at time intervals over $4 \mathrm{~h}$. We considered the 4 -h period to represent baseline values (return to routine metabolic rate), given that previous studies have demonstrated that metabolic rate recovers in that time period (Brett 1964; Redpath et al. 2010), although we acknowledge that the values we recorded after $4 \mathrm{~h}$ were higher than true standard metabolic rate. Recovery rates were determined using closed-system respirometry as described by Steffensen (1989), where oxygen consumption is measured by calculating the amount of $\mathrm{O}_{2}$ depletion in the respirometry chamber when the flush pump (the pump that brings fresh river water into the chamber) is turned off. Oxygen concentrations in the chambers were measured using dissolved oxygen probes (Qubit Systems, S120 dissolved $\mathrm{O}_{2}$ probe; accuracy, $\pm 0.2 \mathrm{mg} / \mathrm{L}$ ) and logged using c901 LoggerPro software, version 3.6.1 (Vernier Software and Technology), connected to a laptop through the c410 LabPro interface (Vernier Software and Technology). The experiment was designed so that the recovery of each fish could be quantified from its oxygen consumption at four time intervals: immedi-
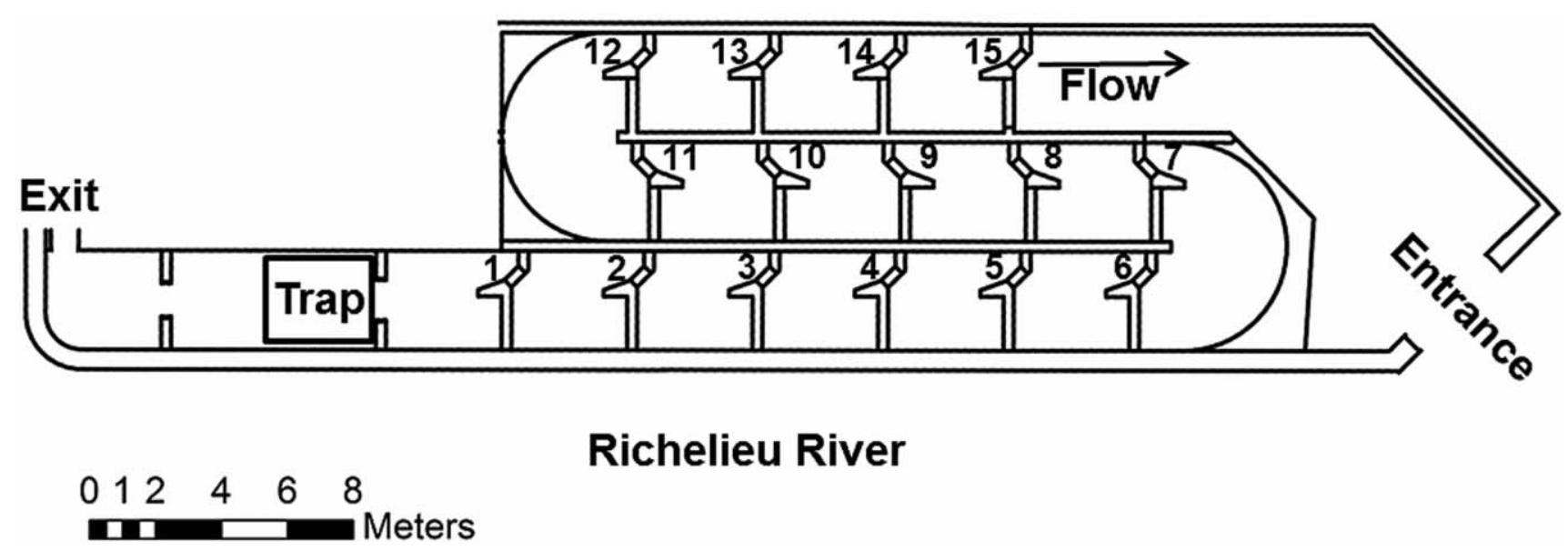

Richelieu River

Figure 1. Schematic of the fishway showing the fishway entrance and exit, the location of the fish trap, the flow direction, and each basin labeled with its corresponding passive integrated transponder antenna number. 
ately after exhaustion, $30 \mathrm{~min}$ after exhaustion, $2 \mathrm{~h}$ after exhaustion, and $4 \mathrm{~h}$ after exhaustion.

Since dissolved oxygen concentrations below $75 \%$ of air saturation levels have been shown to have negative effects on the swimming ability of some fishes (Dahlberg 1968), measurement cycles were calibrated for different size classes of fish. Fish greater than $1.5 \mathrm{~kg}$ were subject to measurement periods of five cycles that consisted of a 2-min measurement phase and 3-min flush phase to replace water in the chamber. Fish weighing between 0.5 and $1.5 \mathrm{~kg}$ were subject to three cycles that consisted of a 5-min measurement phase and 3-min flush phase. Fish under $0.5 \mathrm{~kg}$ in weight were subject to two cycles that consisted of a 10-min measurement phase and 3-min flush phase. Oxygen consumption values across each measurement phase were averaged for each respective recovery period.

The change in oxygen concentration was calculated using the following equation:

$$
\mathrm{MO}_{2}=\alpha V_{\text {resp }} M_{\mathrm{b}}^{-1}
$$

where $\mathrm{Mo}_{2}$ represents the oxygen consumption in milligrams of oxygen per kilogram of fish per hour $\left(\mathrm{MO}_{2}=\mathrm{mg} \mathrm{O} \mathrm{Kg}^{-1}\right.$ $\left.\mathrm{h}^{-1}\right), \alpha$ is the change in oxygen concentration for each fish $\left(\Delta \mathrm{O}_{2 \text { saturation }} / \Delta t\right), V_{\text {resp }}$ is the volume of the respirometer minus the volume of the fish (L), and $M_{\mathrm{b}}$ is the mass $(\mathrm{kg})$ of the fish (Steffensen 1989). Calculated $\mathrm{O}_{2}$ consumption rates were adjusted for background $\mathrm{O}_{2}$ consumption by running a background respirometer and subtracting the values calculated for the background chamber from those calculated for the chambers containing fish. Oxygen probes were calibrated following the guidelines provided in the Qubit Systems manual before each trial was conducted.

\section{Relative Swimming Ability}

Relative swimming ability between the three redhorse species ( $n=60$ per species; silver redhorse, $520 \pm 7 \mathrm{~mm} \mathrm{TL}$; river redhorse, $608 \pm 5 \mathrm{~mm}$ TL; shorthead redhorse, $404 \pm 4 \mathrm{~mm}$ TL) was tested by swimming individual fish to exhaustion in an annular swim flume $130 \mathrm{~cm}$ in diameter with water that was $40 \mathrm{~cm}$ deep (e.g., Portz 2007). Water was refreshed between fish and was obtained from the river such that temperatures were the same as the water in the tanks where they were held prior to experimentation. The annular swim flume was divided into four quadrants, and the number of quadrants each fish passed through was recorded for the first $20 \mathrm{~s}$ of swimming to allow for the calculation of relative swimming speed. The total distance swam by each fish until exhaustion was also recorded. Since fish almost always swam around the outside edge of the flume ( $>95 \%$ of the time), the distance swam by each fish per quadrant was the total circumference of the flume divided by four, or $1.02 \mathrm{~m}$ (the inner circumference of the flume divided by four was $0.48 \mathrm{~m}$ ). Fish were determined to be exhausted when they were no longer able to regain equilibrium (right themselves) after 2 s. Equilibrium was used as the measure of exhaustion because some of the redhorse species (silver and river redhorse) did not respond to tail grabbing. This relative measure of swimming performance has been used in the past by others (see Portz 2007). Although the actual values are not a direct measure of swimming ability, the relative differences among groups (or species) is relevant. Swimming speeds were
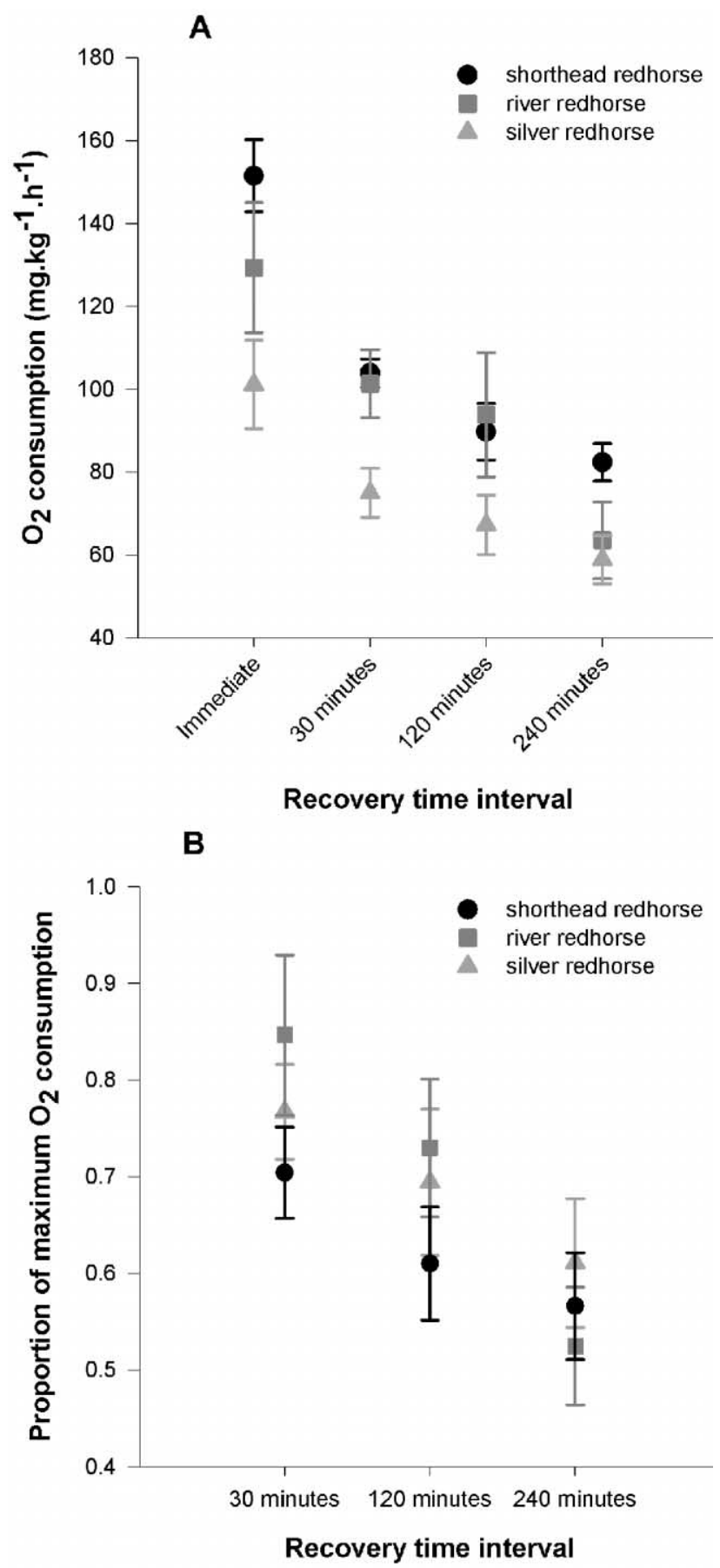

Figure 2. A, Oxygen consumption (in milligrams per kilogram hour) for four time periods after exhaustive exercise for three redhorse species. $B$, Percent of maximum consumption (the "immediate" group from $A$ ) for the three redhorse species for the three time periods after exhaustive exercise: 30,120 , and $240 \mathrm{~min}$. 
Table 1: Results of two-way ANOVAs performed for three blood variables, lactate, glucose, and $\mathrm{pH}$, with species, recovery time interval, and species $\times$ recovery time interval as effects

\begin{tabular}{|c|c|c|c|c|c|c|c|c|c|}
\hline \multirow[b]{2}{*}{ Blood variable } & \multicolumn{3}{|c|}{ Species } & \multicolumn{3}{|c|}{$\begin{array}{c}\text { Recovery time } \\
\text { interval }\end{array}$} & \multicolumn{3}{|c|}{$\begin{array}{c}\text { Species } \times \text { recovery } \\
\text { time interval }\end{array}$} \\
\hline & $F$ & $\mathrm{df}$ & $P$ & $F$ & $\mathrm{df}$ & $P$ & $F$ & $\mathrm{df}$ & $P$ \\
\hline Lactate & 5.26 & 2 & .006 & 105.18 & 5 & $<.001$ & 5.899 & 10 & $<.001$ \\
\hline Glucose & 5.31 & 2 & .006 & 16.11 & 5 & $<.001$ & 2.75 & 10 & .004 \\
\hline $\mathrm{pH}$ & 2.32 & 2 & .102 & 7.401 & 5 & $<.001$ & .967 & 10 & .475 \\
\hline
\end{tabular}

Note. Each two-way ANOVA compared three redhorse species (silver redhorse, river redhorse, and shorthead redhorse) with six recovery time intervals (fish trap, baseline, half hour, $1 \mathrm{~h}, 2 \mathrm{~h}$, and $4 \mathrm{~h}$ ) for each particular blood variable taken from individual fish. Italicized values represent those that are significant at $P<0.05$.

normalized by converting data to body lengths swam per distance unit $(\mathrm{cm})$ per second.

\section{Blood Physiology Profiles}

To generate physiological recovery profiles for each species, we placed fish in hypolon fish-carrying bags (FT940 recovery bags; Dynamic Aqua Supply, Vancouver, British Columbia; length, $101 \mathrm{~cm}$; diameter, $23 \mathrm{~cm}$, with $0.5-\mathrm{cm}$ mesh on both ends) after exhaustion. Recovery profiles were generated by blood sampling fish for glucose, lactate, and $\mathrm{pH}$ levels at six different time intervals, creating six recovery groups $(n=10$ fish per species per time interval; no fish was sampled more than once). The first recovery group contained fish that were blood sampled immediately (within 1 min of landing) after they were dipnetted out of the fish trap at the top of the fishway. The second recovery group contained fish used as the baseline group. Fish in the second recovery group were not swum to exhaustion, and after the initial minimum holding time of $24 \mathrm{~h}$ had passed, these fish were placed in recovery bags for $24 \mathrm{~h}$ (to avoid any influence of handling stress) and then blood sampled. Fish recovery groups three, four, five, and six were blood sampled after being in recovery bags for $0.5,1,2$, and $4 \mathrm{~h}$, respectively, after swimming to exhaustion. Upon removal from recovery bags or upon capture (first group), fish were immediately placed in a water-filled v-shaped trough in a supine position and nonlethally blood sampled via caudal puncture using 3-mL vacutainers (Becton Dickinson, Mississauga, Ontario) and 21-gauge needles (Cooke et al. 2005b). Blood samples ( 1 mL was collected from each fish) were placed in a water-ice slurry and analyzed within $10 \mathrm{~min}$ of collection for glucose, lactate, and pH levels. Glucose levels were measured using Accu-chek Compact Plus glucose meters (Roche Diagnostics, Indianapolis, IN), and lactate levels were measured using the Lactate Pro LT-1710 Analyzer (Arkay, Kyoto, Japan). These physiological measurement tools have previously been validated as blood diagnostic tools for fish, providing results that are comparable to those given by laboratory tools (e.g., Venn Beecham et al. 2006; Cooke et al. 2008). Blood $\mathrm{pH}$ was measured using the mini-lab IQ128 $\mathrm{pH}$ meter (accuracy of $\pm 0.02 \mathrm{pH}$ ).

\section{Passage Success and Duration}

Fish used for the determination of passage success were not held in recovery basins for $24 \mathrm{~h}$ prior to experimentation but were tagged immediately after capture from the fish trap at the top of the fishway. The three redhorse species were tagged (silver, $n=120$; river, $n=70$; shorthead, $n=120$ ) with uniquely coded passive integrated transponder (PIT) tags $(23 \times 3.85-\mathrm{mm}$ Half Duplex; Texas Instruments, Dallas, TX) inserted into their peritoneal cavity (for more details on the tagging procedure, see Thiem et al. 2013). TL of each fish was measured, along with a determination of sex accomplished through visual identification (abdominal pressure and gamete extrusion as well as the presence of tubercles on the caudal fin and snout). Following tagging, fish were released approximately $200 \mathrm{~m}$ downstream of the fishway in equal numbers on both river banks. The average approximate time between capture and release for tagged fish was $2 \mathrm{~h}$. Passage success, described as a fish successfully moving past the most upstream antenna, was then determined using the PIT antenna array described by Thiem et al. (2013). Fish detected on the most downstream antenna (antenna 15) were considered to be inside the fishway (see fig. 1) and were therefore included in the calculation of passage efficiency. Passage duration was determined by calculating the time taken from a fish's first detection on the most downstream antenna to the first detection on the most upstream antenna (Thiem et al. 2011, 2013). Fish were tagged during the height of the migratory period respective for their species; silver and shorthead redhorse were tagged between May 5 and May 14, 2012, and river redhorse were tagged between May 24 and May 25, 2012. Fish are thought to be motivated to pass the fishway due to the presence of good spawning habitat at a set of rapids $\sim 50 \mathrm{~km}$ upstream of the fishway, and this is supported by the large numbers of redhorse documented passing the fishway every spawning season (Quebec Ministère des Ressources Naturelles et de la Faune, unpublished data). The fishway was monitored for passage between May 14 and July 10, 2012. 


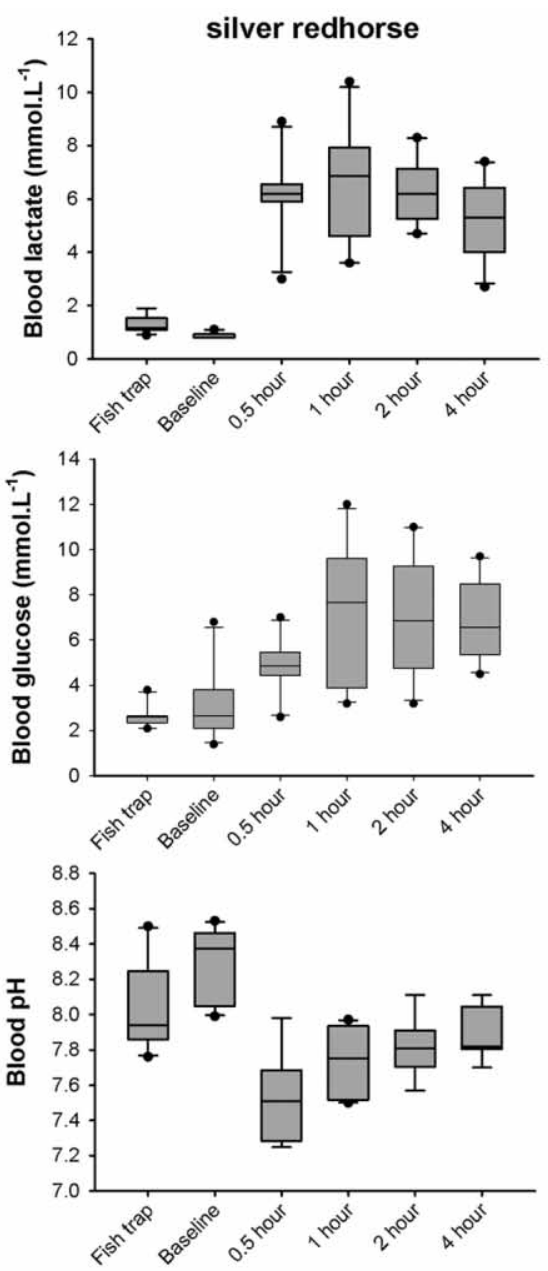

Recovery group
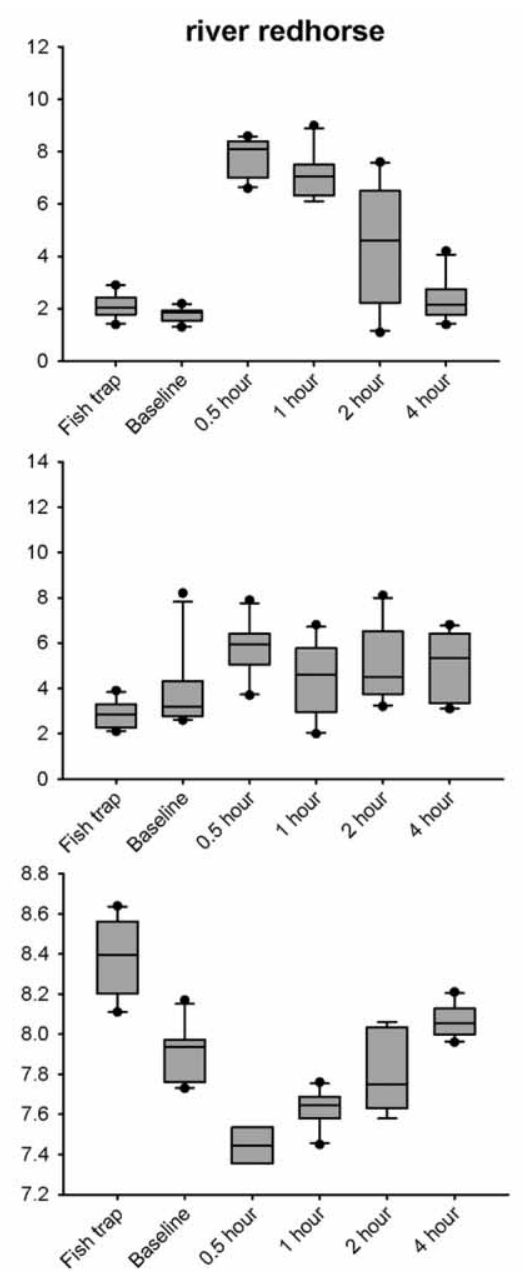

Recovery group
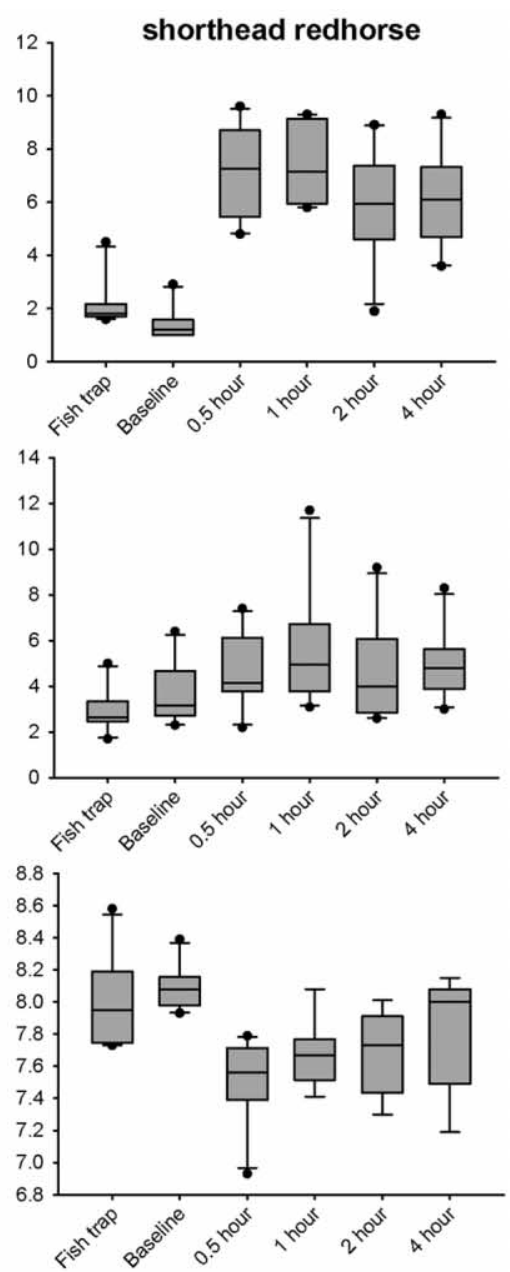

Recovery group

Figure 3. Box and whisker plots showing recovery profiles for blood lactate $\left(\mathrm{mmol} \mathrm{L}^{-1}\right)$, blood glucose $\left(\mathrm{mmol} \mathrm{L}^{-1}\right)$, and blood $\mathrm{pH}$ for three redhorse species (Moxostoma anisurum, Moxostoma carinatum, and Moxostoma macrolepidotum, respectively) over six different recovery profiles. Fish trap results show fish sampled immediately after being dippednetted out of the fish trap. Baseline results show results after fish have been held in recovery bags for $24 \mathrm{~h}$. Time periods of $0.5,1,2$, and $4 \mathrm{~h}$ show the time fish were allowed to recover in recovery bags before being blood sampled. The whiskers represent the tenth and ninetieth percentiles.

\section{Data Analysis}

Changes in oxygen consumption for the four recovery groups were analyzed using a two-way repeated-measures ANOVA; pairwise comparisons were performed using Bonferroni post hoc tests. Changes in blood lactate, glucose, and $\mathrm{pH}$ levels were analyzed using separate two-way ANOVAs; significant interactions were investigated using Holm-Sidak and Bonferroni post hoc tests. Differences in relative swimming speed and time to exhaustion between the three species were analyzed using separate one-way ANOVAs; significance was investigated using Tukey's HSD test. Assumptions for all analyses (including sphericity for the repeated-measures ANOVA) were checked according to Field (2009). All effects were reported as significant at $P<0.05$. All analysis was performed using SigmaStat (SigmaPlot 11) or PASW Statistics 18 (SPSS).

\section{Results}

Respirometry Study

Oxygen consumption during recovery following chase to exhaustion differed among species. There was a significant main effect of species on oxygen consumption $\left(F_{\mathrm{s}}=5.95\right.$, $\mathrm{df}=$ $2,16, P=0.015$; fig. 2). Shorthead redhorse had oxygen consumption values significantly higher than those of silver redhorse $(P=0.001)$ but not significantly higher than those of river redhorse $(P=0.350)$. Additionally, river redhorse oxygen consumption was not significantly higher than silver redhorse consumption $(P=0.106)$. There was also a significant main effect of recovery interval on oxygen consumption $\left(F_{\mathrm{s}}=\right.$ 45.31 , $\mathrm{df}=3,24, P<0.001$; fig. $2 A$ ) where oxygen consumption peaked immediately following exercise and then decreased to 


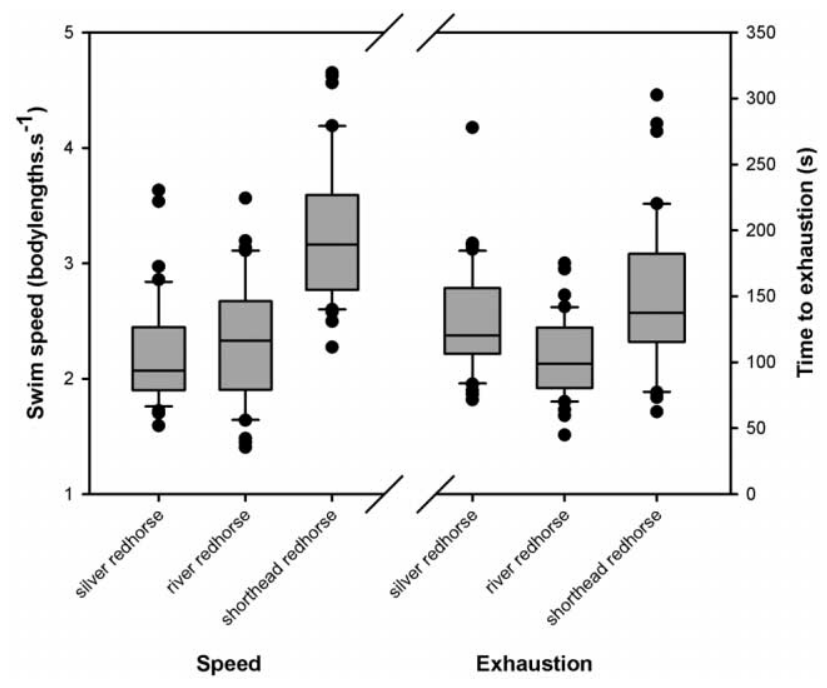

Figure 4. Relative swimming speed (body lengths $\mathrm{s}^{-1}$ ) and the time taken to reach exhaustion (s) for three redhorse species.

some extent by $2 \mathrm{~h}$ after exercise. Pairwise comparisons for recovery intervals revealed that significant differences existed between all recovery intervals $(P<0.001)$ except for the comparison between the 0.5 - and 2 -h recovery groups $(P=$ 0.078 ) and the comparison between the 2- and 4-h recovery groups $(P=0.064)$. There was no significant interaction effect between species and the recovery interval. Shorthead redhorse also recovered the largest proportion of their maximum $\mathrm{O}_{2}$ consumption the fastest, with silver redhorse and river redhorse recovering at approximately the same rate (fig. $2 B$ ).

\section{Blood Analyses}

There was a significant interaction effect between species and recovery interval for blood lactate concentrations $\left(F_{\mathrm{s}}=5.899\right.$, $\mathrm{df}=10,162, P<0.001$; table 1$)$. Silver redhorse had lactate levels significantly lower than those of river redhorse at the 0.5 h $(P=0.006)$ time interval but had lactate levels significantly higher than those of river redhorse at the 2-h $(P=0.002)$ and 4-h $(P<0.001)$ time intervals. Shorthead redhorse had lactate levels significantly higher than those of river redhorse at the 2$\mathrm{h}(P=0.015)$ and 4 -h $(P<0.001)$ time intervals. No other comparisons were significant (fig. 3).

There was also a significant interaction effect between species and recovery interval for blood glucose concentrations $\left(F_{\mathrm{s}}=\right.$ 2.753, $\mathrm{df}=10,162, P=0.004$; table 1$)$. Silver redhorse had glucose levels significantly higher than those of river redhorse at the 1 -h $(P<0.001), 2-\mathrm{h}(P=0.001)$, and 4 -h $(P=0.012)$ intervals. Additionally, silver redhorse had glucose levels significantly higher than those of shorthead redhorse at the 2-h $(P=0.009)$ and 4 -h $(P=0.013)$ time intervals. No other comparisons were significant (fig. 3 ).

No effect of species on blood $\mathrm{pH}$ was found, and there was no significant interaction effect between species and recovery group; however, a significant effect of recovery group on blood $\mathrm{pH}$ levels was identified $\left(F_{\mathrm{s}}=5.32, \mathrm{df}=10,153, P<0.001\right.$; table 1). The baseline and fish trap groups had $\mathrm{pH}$ levels significantly higher than those of all other time interval groups $(P<0.03)$ except at the 4 -h time interval (the baseline group did not differ significantly from the 1-h time interval group; $P=0.056)$. In general, $\mathrm{pH}$ values dropped after exercise and then rebounded to near preexercise levels after $4 \mathrm{~h}$ of recovery (fig. 3).

\section{Swimming Speed Analysis}

We identified a significant effect of species on swimming speed $\left(F_{\mathrm{s}}=47.47, \mathrm{df}=2,117, P<0.001\right.$; fig. 4$)$. All three species differed significantly $(P<0.001)$ in their relative swimming speeds (i.e., shorthead redhorse swam the fastest, river redhorse had intermediate swim speeds, and silver redhorse were the slowest).

Similarly, we identified a significant effect of species on time to exhaustion $\left(F_{\mathrm{s}}=10.95, \mathrm{df}=2,117, P<0.001\right.$; fig. 4$)$. River redhorse became exhausted sooner than both shorthead redhorse $(P<0.001)$ and silver redhorse $(P<0.05)$. There was no significant difference in the time to exhaustion between silver redhorse and shorthead redhorse $(P>0.05)$.

\section{Passage Success and Duration}

In 2012, silver redhorse had the highest passage efficiency between the three species, with an $88 \%$ success rate (table 2 ). Shorthead redhorse followed with $69 \%$ success, with river redhorse having the lowest passage success rate at 50\%. Silver redhorse also had the shortest passage duration times, with a median passage duration time of $0.94 \mathrm{~h}$. River redhorse had the second-shortest passage duration time, with a value of 1.95 $\mathrm{h}$ (only one record was available). Shorthead redhorse had the longest passage duration times, with a median value of $5.14 \mathrm{~h}$.

\section{Discussion}

Relative metabolic recovery rates differed significantly between shorthead and silver redhorse; however, river redhorse did not have significantly different recovery rates than either of the other two species. Shorthead redhorse were also able to recover a larger proportion from their maximum oxygen consumption rate more quickly than the other two species. Oxygen consumption rates for actively swimming Catostomus commersoni (white sucker; see Saunders 1982; Thurston and Gehrke 1993) were higher than the rates we obtained for three redhorse species immediately after exercise. It is important to note, however, that the values for white sucker were taken at higher temperatures. Relevant here is the fact that we did not measure oxygen consumption at the same temperature for the three species studied. Instead, we conducted respirometry trials at temperatures that coincided with peak migration time for each species. Clearly, some of the interspecific variation in respiration noted here might be expected to be driven by the influence of water temperature on fish metabolism (Fry 1971). That said, the high- 
Table 2: Passage efficiency and duration results for three species of redhorse for the Vianney-Legendre fishway, shown for two separate years of study

\begin{tabular}{|c|c|c|c|c|c|c|}
\hline Year and species & Total length $(\mathrm{mm})$ & $\begin{array}{l}\text { No. } \\
\text { tagged }\end{array}$ & $\begin{array}{c}\text { No. } \\
\text { attempted }\end{array}$ & $\begin{array}{c}\text { No. } \\
\text { passed }^{\mathrm{a}}\end{array}$ & $\begin{array}{c}\text { Passage } \\
\text { efficiency } \\
(\%)\end{array}$ & Passage duration $(\mathrm{h})^{\mathrm{b}}$ \\
\hline \multicolumn{7}{|l|}{ 2010: } \\
\hline Silver redhorse & $432.4 \pm 12.4 ; 220-598$ & 42 & 10 & 3 & 30 & $2.6 \pm 1.3 ; \underline{1.6} ; 1.0-5.2(3)$ \\
\hline River redhorse & $559.7 \pm 8.7 ; 312-679$ & 87 & 26 & 8 & 31 & $5.6 \pm 1.1 ; \overline{5.3} ; 1.0-11.4(8)$ \\
\hline Shorthead redhorse & $360.3 \pm 6.3 ; 255-540$ & 74 & 22 & 10 & 46 & $81.2 \pm 38.1 ; \underline{57.6} ; 2.4-237.5(6)$ \\
\hline \multicolumn{7}{|l|}{ 2012: } \\
\hline Silver redhorse & $549.0 \pm 4.8 ; 440-622$ & 120 & 60 & 53 & 88 & $7 \pm 4 ; .94 ; .4-140(38)$ \\
\hline River redhorse & $631.8 \pm 10.6 ; 551-681$ & 70 & 12 & 6 & 50 & $2 \pm .6 ; \overline{2.0} ; 1-3(3)$ \\
\hline Shorthead redhorse & $417.7 \pm 3.9 ; 355-490$ & 120 & 61 & 42 & 69 & $51 \pm 11 ; \overline{5.14} ; .3-217(35)$ \\
\hline
\end{tabular}

Note. Data for 2010 were taken from Thiem et al. (2013). Data for 2012 show passage information for the 2012 season. Data for total length and passage duration are initially displayed in terms of mean $\pm \mathrm{SE}$, followed by range values (minimum-maximum). Median values for passage duration are underlined.

aThe number of individuals reaching the most upstream antenna.

${ }^{\mathrm{b}}$ The numbers in parentheses represent the number of individuals for which passage duration could be calculated.

est-temperature group was the river redhorse, yet their metabolic rate was intermediate between the other two species. Recent work on Pacific salmon suggests population-specific relationships between metabolic performance and temperature, reflecting historic river conditions (e.g., Eliason et al. 2011), and we would predict the same for redhorse at the species level. Oxygen consumption rates that we obtained from three species of redhorse (after $4 \mathrm{~h}$ of recovery) are comparable to those published for white sucker at rest (see Beamish 1974; Clarke and Johnston 1999) but are lower than the white sucker values reported by Altman and Katz (1971) and Thurston and Gehrke (1993). We are unaware of any previous respirometry work on the three redhorse species studied here. Independent of the influence of temperature, it is not surprising that the three species we studied showed different oxygen consumption rates, as several studies have shown that even congeneric species can exhibit different rates of oxygen consumption while at rest (Basu 1959; Brett 1972; Beamish 1974). However, it is interesting that while silver redhorse and shorthead redhorse showed the greatest recovery from maximum oxygen consumption within the first half hour after exhaustion exercise, river redhorse had their largest proportion of recovery from maximum consumption in the third and fourth hours after exercise. This suggests that river redhorse may require more resting time than the other two species.

Examining the blood physiology of the three redhorse species before and after exhaustive exercise showed recovery patterns typical of teleost fish following exhaustive exercise, namely, an increase in blood lactate and blood glucose and a decrease in blood $\mathrm{pH}$, with values typically deviating maximally from rest within 1 to $2 \mathrm{~h}$ after exercise (Wood 1991; Kieffer 2000). Four hours after exercise, recovery to near baseline lactate levels occurred only in the river redhorse, but $\mathrm{pH}$ values for all three species were close to baseline levels. Blood glucose levels for all three species showed recovery patterns consistent with an eventual return to baseline levels but had yet to return to near baseline values after $4 \mathrm{~h}$ of recovery. Black (1960) showed that blood lactate levels can remain above baseline levels in strenuously exercised (fish chased in a circular hatchery trough) rainbow trout (Oncorhynchus mykiss) for up to $8 \mathrm{~h}$ after exercise, and glucose levels remained elevated for up to $24 \mathrm{~h}$. Similarly, a study by Schwalme and Mackay (1985) on northern pike (Esox lucius) showed blood lactate levels above baseline levels for up to $8 \mathrm{~h}$ after exercise, blood glucose levels above baseline values for up to $12 \mathrm{~h}$, and blood $\mathrm{pH}$ values returning to baseline levels $8 \mathrm{~h}$ after exercise. Silver and shorthead redhorse showed results similar to those found in the above-mentioned studies; however, river redhorse appear to have recovered to baseline lactate and $\mathrm{pH}$ levels more quickly than rainbow trout and northern pike. Of particular interest for this study are the results from the blood samples taken from fish out of the fish trap. The lactate, glucose, and $\mathrm{pH}$ levels measured from fish sampled directly from the fishway are lower (or higher for $\mathrm{pH}$ ) than laboratory controls. Moreover, the physiological profiles from fish sampled from the fishway trap at the top of the fishway are nowhere near the more altered values obtained following exhaustive manual chasing. Essentially, fish did not seem to be exerting themselves to the same level in the fishway as they were when manually chased to exhaustion. While fish in the fish trap may have been resting in the trap area instead of having recently moved into the trap, past experience (J. D. Thiem, unpublished data) at this site suggests that fish are routinely moving in and out of the fish trap, sometimes moving down almost to the fishway entrance before reascending. In fact, we may have expected to see more extreme variation in those samples, but that was not the case. Additionally, the maximum time fish could have been in the trap was $24 \mathrm{~h}$, as the trap was emptied each day. Even while in the trap, fish would have been exposed to various stressors (including captivity, crowding, attempts to escape), so it is noteworthy (based on the swimming speed results discussed below) that the values from those fish are less disturbed (i.e., lactate and glucose lower and $\mathrm{pH}$ higher) than those from control fish held in sensory deprivation chambers and sampled after $24 \mathrm{~h}$. 
Table 3: Summary table ranking silver, river, and shorthead redhorse according to their respective experimental performance

\begin{tabular}{lccc}
\hline & $\begin{array}{c}\text { Silver } \\
\text { redhorse }\end{array}$ & $\begin{array}{c}\text { River } \\
\text { redhorse }\end{array}$ & $\begin{array}{c}\text { Shorthead } \\
\text { redhorse }\end{array}$ \\
\hline Metabolic recovery & 3 & 2 & 1 \\
Lactate recovery & 2 & 1 & 3 \\
Glucose recovery & 1 & 1 & 1 \\
pH recovery & 2 & 1 & 3 \\
Swim speed & 3 & 2 & 1 \\
Time to exhaustion & $2^{\mathrm{a}}$ & $3^{\mathrm{a}}$ & $1^{\mathrm{a}}$ \\
Passage success 2010 & 3 & 2 & 1 \\
Passage success 2012 & 1 & 3 & 2 \\
Duration 2010 & $1^{\mathrm{b}}$ & $2^{\mathrm{b}}$ & $3^{\mathrm{b}}$ \\
Duration 2012 & $1^{\mathrm{b}}$ & $2^{\mathrm{b}}$ & $3^{\mathrm{b}}$ \\
\hline
\end{tabular}

Note. 1 = highest rank; $3=$ lowest rank

${ }^{a}$ As a longer time to exhaustion is seen as beneficial rather than detrimental to passage success, a score of 1 was given to shorthead redhorse, 2 to silver redhorse, and 3 to river redhorse.

${ }^{\mathrm{b}}$ Median value used.

Shorthead redhorse swam the fastest ( 3.3 body lengths [BL] $\left.\mathrm{s}^{-1}\right)$ and took the longest time to reach exhaustion. River redhorse swam the second fastest $\left(\sim 2.5 \mathrm{BL} \mathrm{s}^{-1}\right)$ but exhausted the fastest, while silver redhorse swam the slowest $\left(\sim 2.1 \mathrm{BL} \mathrm{s}^{-1}\right)$ and were second in terms of time to exhaustion (fig. 4). Jones et al. (1974) reported average critical swim speeds $\left(U_{\text {crit }}\right)$ of 2.16 $\mathrm{BL} \mathrm{s}^{-1}$ for Catostomus catostomus (longnose sucker) and 2.25 $\mathrm{BL} \mathrm{s}{ }^{-1}$ for white sucker. Our study tends to support the findings of Portz (2007) that swim speeds obtained using the same methods we used here are generally similar to the $U_{\text {crit }}$ values of fish obtained using other forced-swimming methods for other catostomids. In terms of exhaustion, few data are available for catostomids (Peake 2008). A study performed on largemouth bass (Micropoterus salmoides) by Gingerich et al. (2010) showed bass (a centrarchid) reaching exhaustion after $\sim 40 \mathrm{~s}$, which is considerably shorter than the times we recorded for three redhorse species.

Our field measures of passage success and behavior varied among years. Passage success in 2012 was higher than in 2010 for silver redhorse and shorthead redhorse but lower for river redhorse (table 2). Interestingly, the rank of redhorse passage success varied among years, which may indicate that larger sample sizes were needed or may reflect the fact that environmental conditions (e.g., rate of river warming) varied among years and may influence interspecific patterns in passage success through time. It is possible that in 2010 passage success numbers were low for silver and shorthead redhorse because of the timing of the study; the study took place at the end of May and beginning of June 2010, and it is possible that peak redhorse migration occurred before that. The low numbers of river redhorse passed in 2012 are perplexing at first glance but may be explained by the installation of a gill net (5-inch mesh size) across the entrance to the fishway on May 28, 2012, for a separate attempt to capture broodstock for the critically en- dangered copper redhorse (Moxostoma hubbsi). The gill net was in place from approximately 9 a.m. to 5:30 p.m. for $2 \mathrm{wk}$ following its installation, and several river redhorse were captured in this net. As a result of the body shape and timing of their respective spawning migrations, we assumed that the gill net had no effect on the silver and shorthead redhorse passage results. Results from Thiem et al. (2013) show river redhorse ascending the fishway mostly during the hours of 11 a.m. to 7 p.m., and therefore, the presence of the gill net may have deterred many fish attempting to reascend the fishway. For comparison, passage success in 2010 at the same fishway was $48.7 \%$ for longnose sucker and $75.8 \%$ for white sucker (Thiem et al. 2013), further demonstrating the rather divergent values in fishway success observed among confamilial species.

We did not develop or test for any quantitative relationships among species-specific physiological characteristics and metrics of passage behavior and success because doing so would create a scenario in which we would lack the statistical power to discern relationships (each species would be a data point). In order to test quantitative relationships, two different approaches could be used. The first approach would require us to perform a study similar to ours but instead look at many more species. Such a study would be possible at the VianneyLegendre fishway because $\sim 40$ species have been reported to pass this fishway. A second approach could look at individual capacity of members of a given species and link that to that individual's behavior and success. Roscoe et al. (2011) studied the fate of upriver-migrating salmon and their respective physiological condition while moving through a fishway by obtaining a nonlethal blood sample and then releasing fish with telemetry transmitters. In both Roscoe et al.'s (2011) article and our study, all fish sampled were successful (i.e., captured and tagged from the fish trap at the top end of the fishway) fish, and perhaps the fish with poor capacity would not make it to the top of the fishway. Unfortunately, we could not perform either of the quantitative tests described above, so we ranked fish to qualitatively observe interspecific trends. Table 3 ranks each species on the basis of their experimental performance and also illustrates their respective passage success and duration. Based on the results from the physiological experiments we performed, we anticipated that shorthead redhorse would be the most successful (highest passage success and shortest passage duration) of the three redhorse species. This was not the case; silver redhorse had the poorest performance in the laboratory but had the highest passage success and shortest passage duration. Clearly, something more than metabolic capacity, physiological status, and swimming performance could be influencing passage success and duration. This premise is supported by the physiological data obtained from the fish trap, which showed that fish were likely not exhausted when they reached the top. Fish that were unsuccessful may have become exhausted during their ascent of the fishway and never made it to the trap to be sampled. It is also possible that unsuccessful fish were confused and could not reach the top due to sensory or behavioral issues despite having the physiological capacity to do so. Had unsuccessful fish been tested, through dipnetting 
in the fishway, it is possible that our results would better reflect fish with poor performance and thus generally be more variable.

\section{Implications for Fishway Science and Practice}

Although we failed to document clear relationships (anecdotal or quantitative) between species-specific physiology and passage success/behavior, this study still has important implications for biological evaluations of fishways. Clearly, additional research is needed to understand how fish performance, environmental conditions, and other factors (including abundance of conspecifics and other comigrants) interact with fishway design features to dictate which fish will be successful and to inform the design of future fishways (Kemp 2012). Noteworthy was the fact that fish sampled from the top of the fishway had physiological profiles that were more similar to control fish rather than fish that were manually exhausted. This information suggests that while physiological capacity is not a limiting factor in relation to passage success, physiology could be used as a tool for determining whether the impediments to passage success are behavioral or related to physiological capacity. As such, a rapid assessment technique could involve measuring blood and muscle physiology (e.g., metabolites, cortisol, ion status, hematology, and tissue energy stores) of fish sampled from the top of this fishway and control fish sampled $30 \mathrm{~min}$ following exposure to manual chasing to elicit physiological exhaustion. Such an approach could identify species (or size classes) that are physiologically taxed from fishway passage and thus that may benefit from further study. This approach could be coupled with sampling of fish throughout the fishway, which would require development of sampling techniques that are effective and capture fish rapidly with minimal stress (see Pon et al. 2012 for an example), to identify potential areas of difficulty within the fishway. In instances where passage success is low yet there is no evidence that fish are physiologically or metabolically taxed from fishway passage, there may be good reason to suspect that the underlying problems are related to motivation or behavioral confusion (e.g., behavioral cues are unclear) rather than a problem with ability. Developing these types of physiological tools is important because physiology has the potential to explain passage performance and enhance the practice of fishway science.

\section{Acknowledgments}

Florent Archambault, Nicholas Burnett, Sylvain Desloges, Jean Leclerc, Guillaume Lemieux, and Travis Raison provided expert field assistance. Parks Canada (André Brunelle, Jean Larochelle, and Guy Noël) provided site access and logistic support. Comments from anonymous reviewers improved the manuscript. Project funding was provided by an NSERC HydroNet Strategic Network grant, an NSERC RTI grant, Natural Resources Canada, Fisheries and Oceans Canada, and the Canadian Wildlife Federation. Significant financial and in-kind contributions were also provided by the Quebec MNRF. S.J.C. was supported by the Canada Research Chair program, and C.H. was supported by an NSERC-CGSM (Alexander Graham Bell) scholarship, an Ontario graduate scholarship (OGS), and additional graduate scholarships from Carleton University. This project was conducted in accordance with the guidelines of the Canadian Council on Animal Care administered by the Carleton University Animal Care Committee (B10-12).

\section{Literature Cited}

Altman P.L. and D.D. Katz, eds. 1971. Respiration and circulation. Federation of American Societies for Experimental Biology, Bethesda, MD.

Basu S.P. 1959. Active respiration of fish in relation to ambient concentrations of oxygen and carbon dioxide. J Fish Res Board Can 16:175-212.

Beamish F.W.H. 1974. Apparent specific dynamic action of largemouth bass, Micropterus salmoides. J Fish Res Board Can 31:1763-1769.

Bernhardt E.S., M.A. Palmer, J.D. Allan, G. Alexander, K. Barnas, S. Brooks, J. Carr, et al. 2005. Synthesizing US river restoration efforts. Science 308:636-637.

Black E.C., A.C. Robertson, A.R. Hanslip, and W.G. Chiu. 1960. Alterations in glycogen, glucose and lactate in rainbow and Kamloops trout, Salmo gardneri, following muscular activity. J Fish Res Board Can 17:487-599.

Brett J.R. 1964. The respiratory metabolism and swimming performance of young sockeye salmon. J Fish Res Board Can 21:1183-1226.

Brett J.R. and N.R. Glass. 1972. Metabolic rates and critical swimming speeds of sockeye salmon (Oncorhynchus nerka) in relation to size and temperature. J Fish Res Board Can 30:379-387.

Bunt C.M., T. Castro-Santos, and A. Haro. 2012. Performance of fishway passage structures at upstream barriers to migration. River Res Appl 28:457-478.

Bunt C.M., C. Katopodis, and R.S. McKinley. 1999. Attraction and passage efficiency of white suckers and smallmouth bass by two Denil fishways. N Am J Fish Manag 19:793-803.

Bunt C.M., B.T. van Poorten, and L. Wong. 2001. Denil fishway utilization patterns and passage of several warm-water species relative to seasonal, thermal and hydraulic dynamics. Ecol Freshw Fish 10:212-219.

Castro-Santos T., A. Cotel, and P.W. Webb. 2009. Fishway evaluations for better bioengineering: an integrative approach. Pp. 575-575 in A. Haro, K.L. Smith, R.A. Rulifson, C.M. Moffit, R.J. Klauda, M.J. Dadswell, R.A. Cunjak, J.E. Cooper, K.L. Beal, and T.S. Avery, eds. Challenges for diadromous fishes in a dynamic global environment. American Fisheries Society, Bethesda, MD.

Castro-Santos T., A. Haro, and S. Walk. 1996. A passive integrated transponder (PIT) tag system for monitoring fishways. Fish Res 28:253-261.

Clarke A. and N.M. Johnston. 1999. Scaling of metabolic rate with body mass and temperature in teleost fish. J Anim Ecol 68:893-905. 
Cocherell D.E., A. Kawabata, D.W. Kratville, S.A. Cocherell, R.C. Kaufman, E.K. Anderson, Z.G. Chen, et al. 2011. Passage performance and physiological stress response of adult white sturgeon ascending a laboratory fishway. J Appl Ichtyol 27: 327-334.

Connor A.R., C.H. Elling, E.C. Black, G.B. Collins, J.R. Gauley, and E. Trevor-Smith. 1964. Changes in glycogen and lactate levels in migrating salmonid fishes ascending experimental endless fishways. J Fish Res Board Can 21:255-290.

Cooke S.J., C.M. Bunt, S.J. Hamilton, C.A. Jennings, M.P. Pearson, M.S. Cooperman, and D.F. Markle. 2005a. Threats, conservation strategies, and prognosis for suckers (Catostomidae) in North America: insights from regional case studies of a diverse family of non-game fishes. Biol Conserv 121: 317-331.

Cooke S.J., G.T. Crossin, D. Patterson, K. English, S.G. Hinch, J.L. Young, R. Alexander, M.C. Healey, G. Van Der Kraak, and A.P. Farrell. 2005b. Coupling non-invasive physiological and energetic assessments with telemetry to understand inter-individual variation in behaviour and survivorship of sockeye salmon: development and validation of a technique. J Fish Biol 67:1342-1358.

Cooke S.J. and C.M. O'Connor. 2010. Making conservation physiology relevant to policy makers and conservation practitioners. Conserv Lett 3:159-166.

Cooke S.J., L. Sack, C.E. Franklin, A.P. Farrell, J. Beardall, M. Wikelski, and S.L. Chown. 2013. What is conservation physiology? perspectives on an increasingly integrated and essential science. Conserv Physiol 1, doi:10.1093/conphys/cot001.

Cooke S.J., C.D. Suski, S.E. Danylchuk, A.J. Danylchuk, M.R. Donaldson, C. Pullen, G. Bulte, et al. 2008. Effects of capture techniques on the physiological condition of bonefish (Albula vulpes) evaluated using field physiology diagnostic tools. J Fish Biol 73:1351-1375.

Dahlberg M., D.L. Shumway, and P. Doudroff. 1968. Influence of dissolved oxygen and carbon dioxide and swimming performance of largemouth bass and coho salmon. J Fish Res Board Can 25:49-70.

Dominy C.L. 1971. Changes in blood lactic acid concentrations in alewives (Alosa pseudoharengus) during passage through a pool and weir fishway. J Fish Res Board Can 28:1215-1217.

Eliason E.J., T.D. Clark, M.J. Hague, L.M. Hanson, Z.S. Gallagher, K.M. Jeffries, M.K. Gale, D.A. Patterson, S.G. Hinch, and A.P. Farrell. 2011. Differences in thermal tolerance among sockeye salmon populations. Science 332:109-112.

Field A.P. 2009. Discovering statistics using SPSS. Sage, Los Angeles.

Fry F.E.J. 1971. The effect of environmental factors on the physiology of fish. Pp. 1-98 in W.S. Hoar and D.J. Randall, eds. Fish physiology. Vol. VI. Academic Press, New York.

Gingerich A.J., D.P. Philipp, and C.D. Suski. 2010. Effects of nutritional status on metabolic rate, exercise and recovery in a freshwater fish. J Comp Physiol B 180:371-384.

Haro A., T. Castro-Santos, J. Noreika, and M. Odeh. 2004. Swimming performance of upstream migrant fishes in open- channel flow: a new approach to predicting passage through velocity barriers. Can J Fish Aquat Sci 61:1590-1601.

Hasler C.T., L.B. Pon, D.W. Roscoe, B. Mossop, D.A. Patterson, S.G. Hinch, and S.J. Cooke. 2009. Expanding the "toolbox" for studying the biological responses of individual fish to hydropower infrastructure and operating strategies. Environ Rev 17:179-197.

Hinch S.G. and J. Bratty. 2000. Effects of swim speed and activity pattern on success of adult sockeye salmon migration through an area of difficult passage. Trans Am Fish Soc 129: 598-606.

Jones D.R., J.W. Kiceniuk, and O.S. Bamford. 1974. Evaluation of the swimming performance of several fish species from the Mackenzie River. J Fish Res Board Can 31:1641-1647.

Katopodis C. and R. Gervais. 2012. Ecohydraulic analysis of fish fatigue data. River Res Appl 28:444-456.

Kemp P.S. 2012. Bridging the gap between fish behaviour, performance and hydrodynamics: an ecohydraulics approach to fishway passage research. River Res Appl 28:403-406.

Kieffer J.D. 2000. Limits to exhaustive exercise in fish. Comp Biochem Physiol A 126:161-179.

Lucas M.C. and E. Baras. 2001. Migration of freshwater fishes. Blackwell Science, Oxford.

Noonan M.J., J.W.A. Grant, and C.D. Jackson. 2012. A quantitative assessment of fishway passage efficiency. Fish Fish 13: 450-464.

Peake S.J. 2008. Swimming performance and behaviour of fish species endemic to Newfoundland and Labrador: a literature review for the purpose of establishing design and water velocity criteria for fishways and culverts. Can Manuscr Rep Fish Aquat Sci 2843.

Peake S.J., C. Barth, and R.S. McKinley. 1997a. Effect of recovery parameters on critical swimming speed of juvenile rainbow trout (Oncorhynchus mykiss). Can J Zool 75:17241727.

Peake S.J., F.W.H. Beamish, R.S. McKinley, D.A. Scruton, and C. Katopodis. 1997b. Relating swimming performance of lake sturgeon, Acipenser fulvescens, to fishway design. Can J Fish Aquat Sci 54:1361-1366.

Peake S.J. and A.P. Farrell. 2004. Locomotory behaviour and post-exercise physiology in relation to swimming speed, gait transition and metabolism in free-swimming smallmouth bass (Micropterus dolomieu). J Exp Biol 2007:1563-1575.

Pon L.B., S.G. Hinch, S.J. Cooke, D.A. Patterson, and A.P. Farrell. 2009. Physiological, energetic and behavioural correlates successful fishway passage of adult sockeye salmon Oncorhynchus nerka in the Seton River, British Columbia. J Fish Biol 74:1323-1336.

Pon L.B., S.G. Hinch, C.D. Suski, D.A. Patterson, and S.J. Cooke. 2012. The effectiveness of tissue biopsy as a means of assessing the physiological consequences of fishway passage. River Res Appl 28:1266-1274.

Portz D.E. 2007. Fish-holding-associated stress in Sacramento River chinook salmon (Oncorhynchus tshawytscha) at South Delta Fish Salvage Operations: effects on plasma constituents, 
swimming performance, and predator avoidance. $\mathrm{PhD}$ diss. University of California, Davis.

Pratt T.C., L.M. O’Connor, A.G. Hallett, R.L. McLaughlin, C. Katopodis, D.B. Hayes, and R.A. Bergstedt. 2009. Balancing aquatic habitat fragmentation and control of invasive species: enhancing selective fishway passage at sea lamprey control barriers. Trans Am Fish Soc 138:652-655.

Redpath T.D., S.J. Cooke, C.D. Suski, R. Arlinghaus, P. Couture, D.H. Wahl, and D.P. Philipp. 2010. The metabolic and biochemical basis of vulnerability to recreation angling after three generations of angling-induced selection in a teleost fish. Can J Fish Aquat Sci 67:1983-1992.

Reid S.M. 2006. Timing and demographic characteristics of redhorse spawning runs in three Great Lakes basin river. J Freshw Ecol 21:249-258.

Rodriguez T.T., J.P. Agudo, L.P. Mosquera, and E.P. Gonzalez. 2006. Evaluating vertical-slot fishway designs in terms of fish swimming capabilities. Ecol Eng 27:37-48.

Roscoe D.W. and S.G. Hinch. 2010. Effectiveness monitoring of fishway passage facilities: historical trends, geographic patterns and future directions. Fish Fish 11:12-33.

Roscoe D.W., S.G. Hinch, S.J. Cooke, and D.A. Patterson. 2011. Fishway passage and post-passage mortality of up-river migrating sockeye salmon in the Seton River, British Columbia. River Res Appl 27:693-705.

Saunders R.L. 1982. The irrigation of the gills in fishes. II. Efficiency of oxygen uptake in relation to respiratory flow activity and concentrations of oxygen and carbon dioxide. Can J Zool 40:817-862.

Schwalme K. and W.C. Mackay. 1985. The influence of exercisehandling stress on blood lactate, acid-base, and plasma glucose status of northern pike (Esox lucius L.). Can J Zool 63: 1125-1129.

Schwalme K., W.C. Mackay, and D. Lindner. 1985. Suitability of vertical slot and Denil fishways for passing north-temperature, nonsalmonid fish. Can J Fish Aquat Sci 42:18151822.
Steffensen J.F. 1989. Some errors in respirometry of aquatic breathers: how to avoid and correct for them. Fish Physiol Biochem 6:49-59.

Thiem J.D., T.R. Binder, J.W. Dawson, P. Dumont, D. Hatin, C. Katopodis, D.Z. Zhu, and S.J. Cooke. 2011. Behaviour and passage success of upriver-migrating lake sturgeon $\mathrm{Aci}$ penser fulvescens in a vertical slot fishway on the Richelieu River, Quebec, Canada. Endanger Species Res 15:1-11.

Thiem J.D., T.R. Binder, P. Dumont, D. Hatin, C. Hatry, C. Katopodis, K.M. Stamplecoskie, and S.J. Cooke. 2013. Multispecies fishway passage behavior in a vertical slot fishway on the Richelieu River, Quebec, Canada. River Res Appl 29: 582-592.

Thurston R.V. and P.C. Gehrke. 1993. Respiratory oxygen requirements of fishes: description of OXYREF, a data file based on test results reported in the published literature. Pp. 95108 in R.C. Russo and R.V. Thurston, eds. Fish physiology, toxicology, and water quality management: proceedings of an international symposium. EPA/600/R-93/157. US Environmental Protection Agency, Washington, DC.

Venn Beecham R., B.C. Small, and C.D. Minchew. 2006. Using portable lactate and glucose meters for catfish research: acceptable alternatives to established laboratory methods? N Am J Aquacult 68:291-295.

Wikelski M. and S.J. Cooke. 2006. Conservation physiology. Trends Ecol Evol 21:38-46.

Williams J.G., G. Armstrong, C. Katopodis, M. Larinier, and F. Travade. 2012. Thinking like a fish: a key ingredient for development of effective fishway passage facilities at river obstructions. River Res Appl 28:407-417.

Wood C.M. 1991. Acid-base and ion balance, metabolism, and their interactions, after exhaustive exercise in fish. J Exp Biol 160:285-308.

Young J.L., Z.B. Bornik, M.L. Marcotte, K.N. Charlie, G.N. Wagner, S.G. Hinch, and S.J. Cooke. 2006. Integrating physiology and life history to improve fisheries management and conservation. Fish Fish 7:262-283. 